\title{
CULINARY TOURISM DEVELOPMENT MODEL IN METRO LAMPUNG CITY
}

\author{
Derinta Entas, Karlina, Rina Kurniawati, Baskoro Harwindito. Sahid Institute of \\ Tourism Jakarta \\ derinta.derinta@gmail.com,124karlina@gmail.com,ditoe_27@yahoo.com, \\ rin.kurniawati@gmail.com
}

\begin{abstract}
The purpose of this research is to explore tourism potential in Metro Lampung. The tourism attraction that is potential in Lampung is its local culinary. Culinary tourism is popular nowadays, given the fact that tourists hunt for local food when they are visiting tourist destination. The purpose of this research firstly is to explore the potential of tourism culinary in Metro Lampung City. Secondly is to find the marketing strategy of tourism culinary in Metro Lampung city. Thirdly is to find out the factors needed in promoting local food as tourism attraction in Metro Lampung City.

The data is collected from observation, interview, document study, and questionnaires. This research employs descriptive qualitative approach. The is data gathered and analyzed using SWOT analysis. The output of this research is a model design of culinary tourism development. A recommended of tourism development model is community based tourism. Community based tourism model is tourism which concerns on local community with their local wisdom.
\end{abstract}

Keywords: Tourism, Culinary, Community, Local Wisdom,

\section{Introduction}

\subsection{Background of Study}

Associated with lifestyle, culinary has become an attribute to tourist destination. The lifestyle of people craving for food is resulted from increasing people welfare, especially in urban areas. Tourist visit destinations surely try the local foods. This trend triggers the rise of culinary tourism in various regions. The diversity in culinary of the Indonesian archipelago is a tremendous capital for tourism industry.

Culinary tourism development model involving the local community is crucial to do. Changes in global tourism industry have affected other cities or regions including Metro city in Lampung Province. Metro Lampung city distinctive culinary has not been recognized and promoted yet. Along with the development of tourism in Lampung province, it is still in search of its identity especially in terms $\mathrm{f}$ culinary tourism. 
Metro city is one of the cities in Lampung province. It is located around 45 $\mathrm{km}$ from the Capital City of Bandar Lampung. Metro city is the largest banana producer in Lampung province that produces 6,521 tons of production per year. The majority of people rely on agriculture and other supporting sectors such as the public sector, trade, transport and communications and construction. Metro City is divided into five regions namely Metro West, Metro Center, South Metro, Metro East and Metro North. Metro Lampung city geographical position is reflected in Figure 1.1.

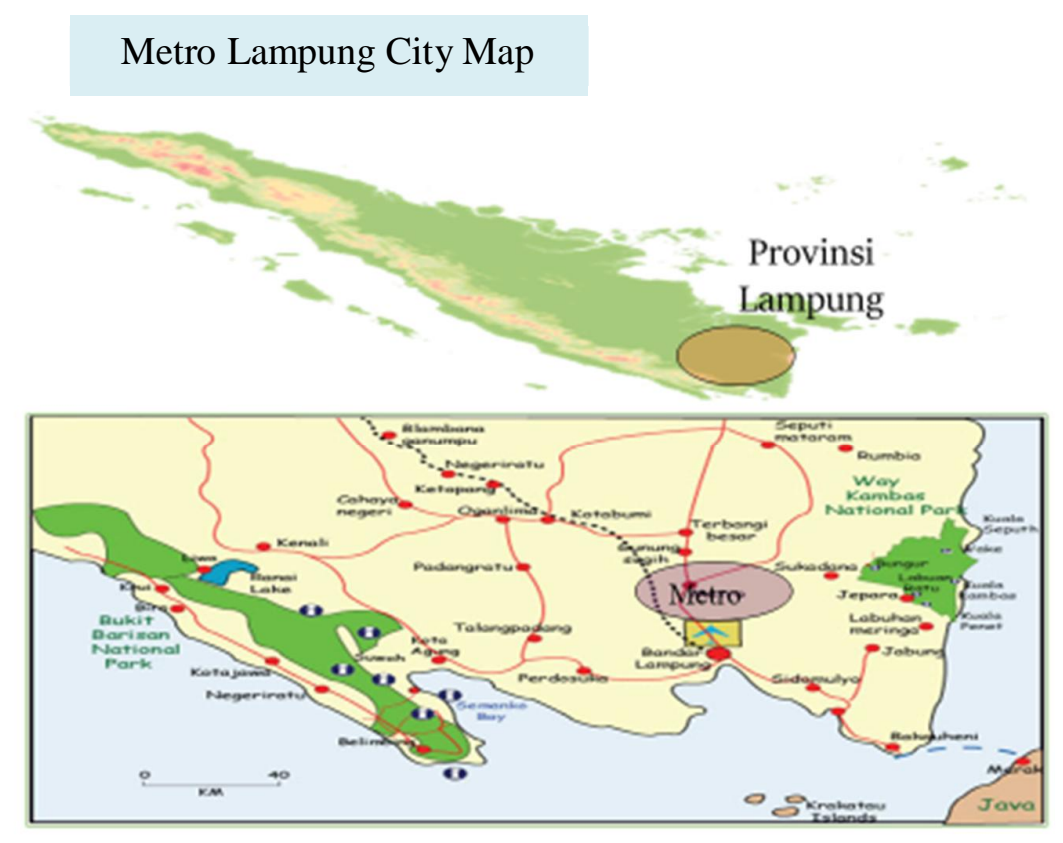

Fig. 1.1 Metro Lampung city map Source: http://www.lampungprov.go.id/\#about-us

Based on the background of this research is, the author is intrigued to develop a model of culinary tourism development in Metro Lampung City. The result of this study recommends a model of tourism development that is based on its typical local food, the bananas. Metro city is potential to develop a souvenir center. The souvenir center will be one place where small and medium enterprises (SMEs) meet and sell their products.

Metro City is a small town that is safe, comfortable and peaceful. It does not have many attractions. Some of the places for tourist attractions are Metro City Park and Dam Raman. Metro Park, the town square Metro Lampung, is called as Taman Merdeka. The location is right in the town center adjoining with the Old Masjid Taqwa vicinity surrounded by beautiful gardens. The city park is a public open space used by communities to come together and work out especially at the weekend. Culinary varieties such as corn, meatballs, mushroom satay, rice tofu, and so forth are available in the town square. Playground for children such as horse-drawn carriages and rickshaws ornamental complete the facilities in the main square of the city. Raman dam is a large dam with beautiful natural scenery and the cool air and green trees around it. The dam is located in the north of Metro 
City; it is a favorite place for the people of Metro. Based on prior observation one of the two places is potential to be developed as souvenir center or exhibition space for Metro typical local products.

The focus of this research is on processed bananas and their derivatives, which have flooded the local market only. Although some have been transferred outside Lampung such as Bandung but the products sold outside do not attach the local label. Processed bananas such as banana chips have become famous in another city well in fact its original production is in Metro Lampung city made by the locals.

Based on this description, this study tries to provide solutions so that local products of Metro Lampung city made by the local community can optimally develop and prosper at local and national market. Strategic marketing is required for product development. This surely relates with the processed banana products and derivatives including flavor, packaging, and types of processed products. In addition, the small and medium enterprises (SMEs) whose members are group of women farmers, and teams of Housewives play a major role in producing processed bananas. This research also identifies strategic location for the distribution of the products. In order to support the tourism sector particularly Lampung Metro city, the local government builds some infrastructure such as star hotels and non-star hotels within the city. Thus, the urgency to strengthen the tourist attraction is present.

\subsection{Research Questions}

Based on the above background, this research would answer the following questions:

a. What are the potentials of culinary tourism in Metro Lampung?

b. What kind of culinary tourism development strategy is suitable for the city?

c. What are the factors needed to consider in promoting local food as the city tourist attraction?

\section{Literature Review}

The concept described in this research is to provide a ground understanding associated of tourism development strategy especially culinary tourism in Metro Lampung. This concept includes development model, culinary tourism, and culinary concept as a tourist attraction.

\subsection{Model Development}

The development model adopted in this study is from Gunn (1972) and Leiper (1981) in which argued that the economic aspects builds a central point with implications on supply factors and demand factors as well as other external factors. Market demand always works together with the provision of infrastructure and services. The two complement each other provide a satisfactory result in the development of tourism. External factors that affect are identified by Gunn in nine factors namely 1) natural resources, 2) cultural resources, 3) organization or leadership, 4) finance, 5) labor, 6) entrepreneurship, 7) community, 8 ) competition, and 9) government policy. Visualization Gunn development model is reflected in this figure below. 


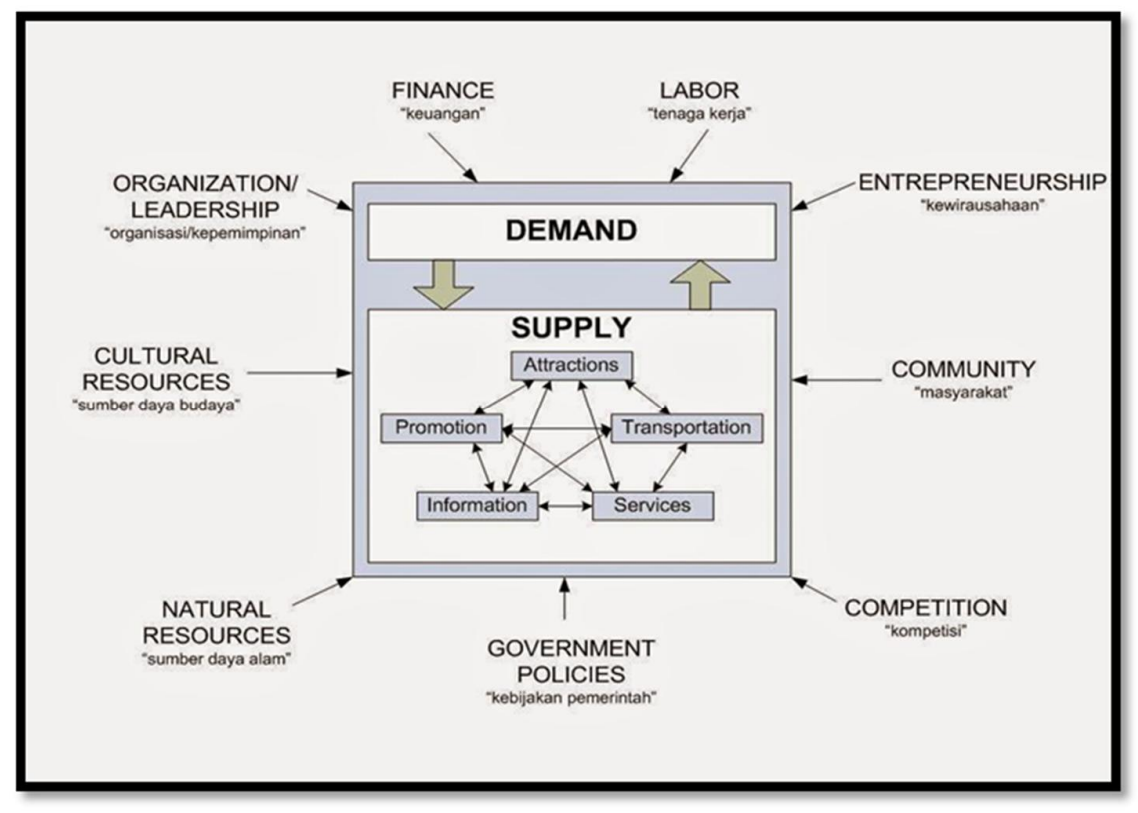

\section{Fig. 2.1 Tourism System Source: Gunn 1972}

\subsection{Culinary Tourism}

Combination of several activities related with enjoyment for a meal when walking, relaxing and traveling to places serving local food is described as culinary tourism. A person's experience of visiting a region and tasting the local food is categorized as culinary tourism. It also includes activities such as cooking school done during the holidays, eating local cuisine in a restaurant, visiting a hawker center, and visiting food-beverage services specifically related to the type of product produced.

Wolf and Suriani (2009:12) described that culinary tourism is not exclusive. It includes any unique and memorable gastronomic restaurant experience not just four star rate restaurant or better but also include all type of food and beverages. The exposure means that culinary tourism is not something fancy and exclusive but more emphasis on the gastronomic experience in which it does not always necessarily deals with the luxury restaurant and completeness of food and beverages available.

\subsection{Culinary as Tourism Attraction}

Tourist attraction is defined as something interesting to see, do, and buy by tourists. While tourist attraction may consist of natural resources, human resources, manmade resources can also be developed and utilized. Based on increasing tourists' interest in local culinary, it has encouraged local culinary as a tourist attraction. Some of the factors that encourage local culinary to become a tourist attraction that is. 1) Increased awareness of travelers to the environment and nutrition or health information of local food, 2) changed in thinking paradigm that food is no longer fulfilling basic need but it has become a lifestyle, 3) 
Increased interest of tourists to learn and understand about the local culture related to food and local drinks.

\section{Methodology}

The data is obtained through observation, interviews, library study, and questionnaires. In this study data is analyzed with descriptive qualitative and interpretation. SWOT analysis formulated by the results of Forum Group Discussion (FGD). The data analysis is carried out in several stages, including: (1) Description of raw material processing of bananas in the local area. (2) Verification of the data related to the processing of raw materials of banana based production with the local community involved; (3) Formulation of a comprehensive field fact findings by comparing and linking relationships among groups. Further relevant theory interpreted and made into conclusions in order to have a new understanding on the issue.

\section{Results and Discussion}

Lifestyle trends supported by increased living standard generate tourism activities. Metro Lampung city, which is the object of this research, has the potential to be one of the culinary tourism destinations. There are three major points outlined in this part. They are: culinary tourism in Metro Lampung city, culinary tourism development strategy, and identification of the factors that can support the local culinary to be tourist attraction in Metro Lampung city. In addition to the three points of discussion, some places that are strategic in supporting local culinary central is recommended as shown in figure 4.1 below.

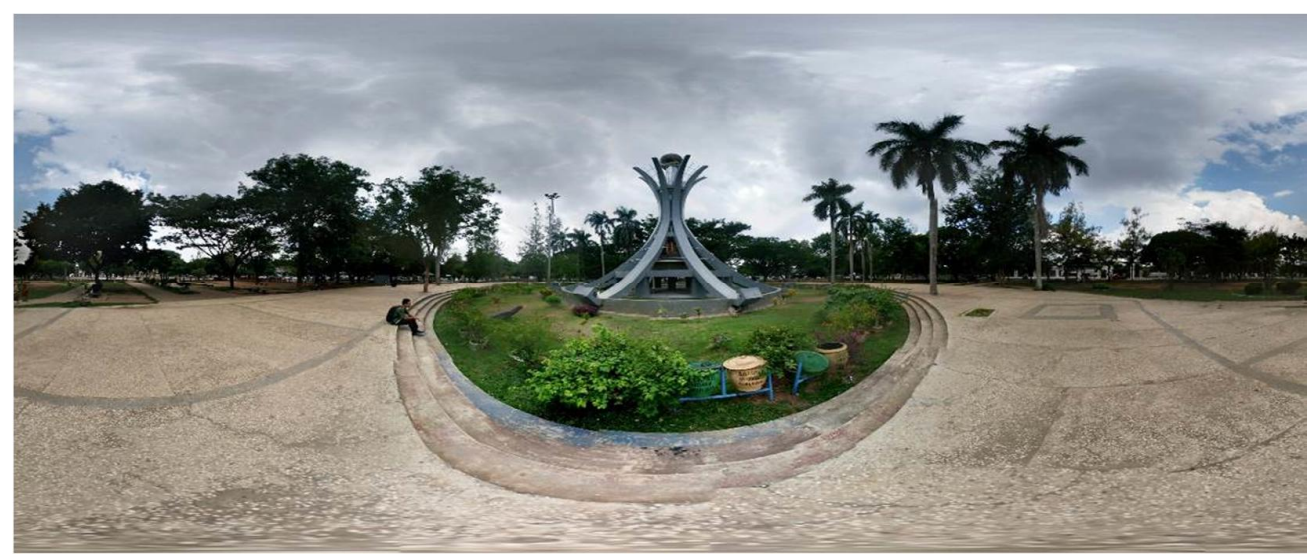

Fig 4.1 Metro Lampung City Park

Source: https://plus.google.com/photos, accessed on 20/06/2016.

\subsection{Culinary Tourism Potentials in Metro Lampung City}

Activities related to the local food of a destination that becomes a trend known as culinary tourism. The identification and field research related to the topic of this study explores the potential of Metro Lampung particularly in regard with local snacks made from bananas. Metro Lampung has culinary tourism potential to be developed, especially snacks made from bananas and their derivative products. The snacks are produced by a group of women farmers who work with home industry, facilitated by the cooperative. 
The results of field observation record that many groups of women farmers produces processed bananas and their derivative products such as banana chips with different flavors, egg roll, banana flour, syrup, banana cake, banana cookies, crackers, and others. The products are mass produced and often abundant in terms of numbers. The products sold in several local shops with poor accessibility. This has become a basis in identifying the potential of Metro Lampung particular culinary tourism. Utilization of bananas provide added value to the city. Currently there are only processed banana chips but because of the hard work, creativity and initiative of the women farmer groups under the guidance of the Ministry of Agriculture, the bananas are processed into a variety of products. Even other parts of plants such as banana fronds, leaves, and stems can be utilized as handcrafts. Crafts include towels, gift bags, gift boxes, and knitted rope for a bottle of syrup as in figure 4.2 below.

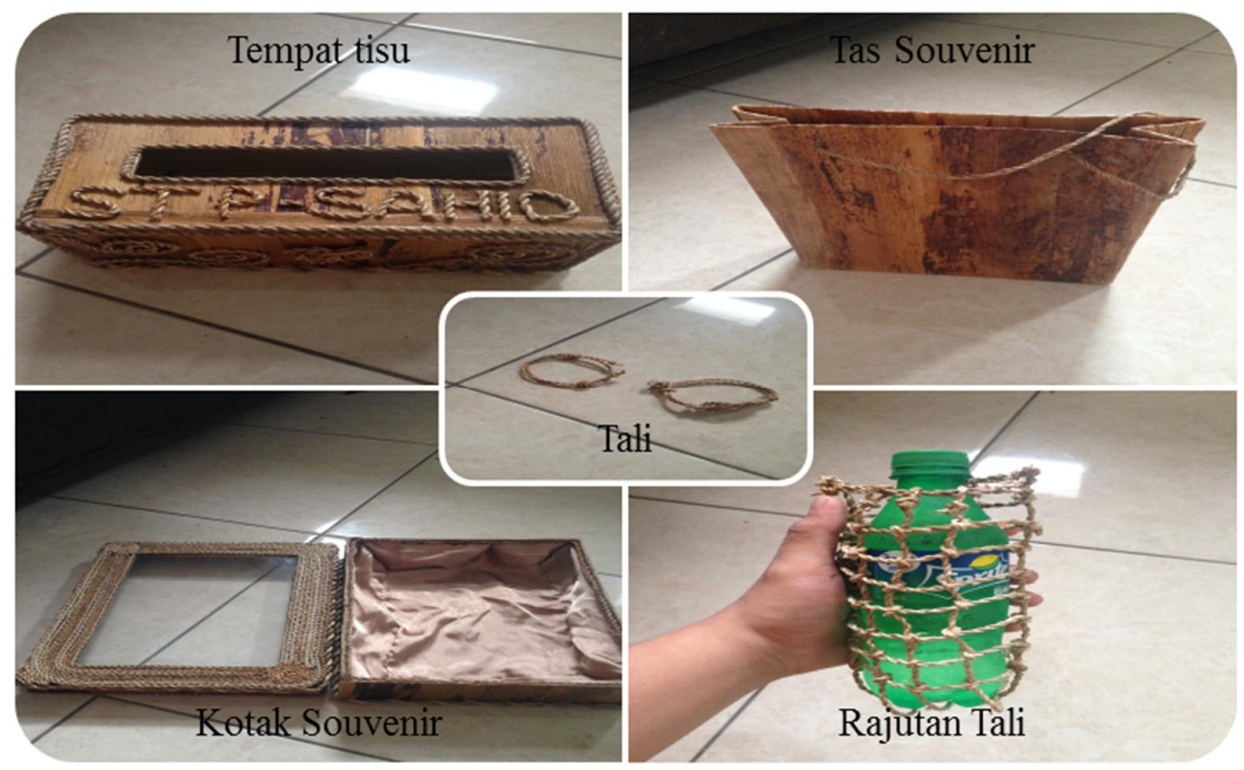

Fig 4.2 Handcrafts made from banana fronds Source: Own documentation, 2016

SWOT analysis is used to analyze the potentials that Metro Lampung has. The SWOT analysis is classified into internal and external factors, as described in the following table.

Table 4.1 SWOT Analysis

\begin{tabular}{|ll|}
\hline Internal Factors & Weaknesses \\
\hline Strenghts & 1. Limited public transportation \\
\hline capital of Bandar Lampung & 2. Lack of interesting tourist attraction \\
2. The second biggest city & 3. Lack of promotion in culinary \\
3. Abundant of bananas & tourism \\
$\begin{array}{l}\text { 4. Has the potential as educational } \\
\text { and culinary tourism. }\end{array}$ & $\begin{array}{l}\text { 4. Limited human resources in terms } \\
\text { of skills in banana processing }\end{array}$
\end{tabular}




\begin{tabular}{|c|c|}
\hline $\begin{array}{l}\text { 5. Sufficient infrastructure and } \\
\text { public areas }\end{array}$ & $\begin{array}{l}\text { 5. Minimum } \\
\text { involvement }\end{array}$ \\
\hline Eksternal Factors & \\
\hline Opportunities & Treats \\
\hline $\begin{array}{l}\text { 1. Designated as autonomous city } \\
\text { 2. Increasing development of } \\
\text { tourism facilities and amenities } \\
\text { 3. Increased number of International } \\
\text { tourists arrival in national scale } \\
\text { 4. Increased national scale tourism } \\
\text { promotional activity } \\
\text { 5. Growing number of creative } \\
\text { industries in other cities }\end{array}$ & $\begin{array}{l}\text { 1. Minimum awareness of the local } \\
\text { youth in local culture } \\
\text { 2. Imported product competition } \\
\text { resulting from ASEAN economic } \\
\text { community } \\
\text { 3. Minimum information on local } \\
\text { tourism development roadmap plan } \\
\text { 4. Development gap between the city } \\
\text { and village } \\
\text { 5. Minimum coordination between } \\
\text { central and local government }\end{array}$ \\
\hline
\end{tabular}

Source: Field observation, 2016.

Based on the SWOT analysis, the author concludes the following main points 1) City Metro has the potential to be developed as a tourist destination, especially in accordance with the culinary tourism potentials of the agricultural sector specifically bananas which can be processed into typical local trademark Metro Lampung city. 2) Snacks bananas and processed derivatives can be used as an iconic identity for the city or Metro Lampung. 3) Other related culinary tourism as cultural heritage needs to be preserved.

\subsection{Culinary Tourism Development Strategy}

The development strategy for culinary tourism, especially in Metro Lampung is summarized in the strategy of tourism destinations namely 1) Push Product, 2) Community Empowerment, 3) Institution and Management 4) Investment (Culinary Tourism Destination Development Policy). These strategies are adapted to the model of the development of culinary tourism in the Metro Lampung as follow: Push Product development is an approach that is based on the potential and the characteristics and advantages of the resources owned by Metro Lampung. Previous statements have described about the potentials owned by Metro Lampung. Reflections on the analysis put processed bananas and derivatives be typical souvenirs from Metro Lampung.

These potentials cannot develop without active participation from the community. Therefore community empowerment is needed. Communities are involved as the owner of the local culinary, so they cultivate a sense of belonging and love when they go to local culinary center in Metro Lampung. Through groups of women farmers, teams of Housewives, SMEs can make the local culinary grow to improve the local economy.

\begin{tabular}{lll} 
& \multicolumn{1}{c}{ Table 4.2 Groups of Women Farmers in Metro Lampung } \\
No & Name of Group & Location \\
$\mathbf{1}$ & Anggrek & East Metro \\
$\mathbf{2}$ & Maju Mulyo & East Metro
\end{tabular}




$\begin{array}{lll}\mathbf{3} & \text { Sehat Sari } & \text { East Metro } \\ \mathbf{4} & \text { Melati } & \text { East Metro } \\ \mathbf{5} & \text { Lancar } & \text { East Metro } \\ \mathbf{6} & \text { Tunas } & \text { West Metro } \\ \mathbf{7} & \text { Mtero Snack } & \text { West Mtero } \\ \mathbf{8} & \text { Restu Ananda YBS } & \text { West Metro } \\ \mathbf{9} & \text { Berkah } & \text { West Metro }\end{array}$

Source: Field Observation, 2015

There are nine women farmers as samples of this study. Five are located in the East and four are located in West Metro. The sample selection is based on the similarity in processed banana production and its derivatives. In addition, research convenience in accessibility is considered.

The third factor is institutional and management in providing the support in the form of synergetic management and regulation. In this case support to the groups of women farmers, teams of housewives, as well as SMEs have been acted properly, especially by the Ministry of Agriculture and the Ministry of Tourism. The support in the form of counseling, coaching in technical skills has taken place. The government and stakeholder have done its role and capacity to achieve the quality of service and quality hospitality management. Another thing to point in these factors, developing and maximizing the use of the public area such as Metro town square can function as a forum where the groups of women farmers, teams of housewives, as well as SMEs to introduce processed banana products and derivatives. Facilitating prestigious events can be done to enhance the competitiveness and skills of the groups of women farmers, teams of Housewives, as well as the SMEs.

Another factor is the Investment support from the government and private parties to groups of women farmers, teams of Housewives and SMEs to join forces in capital, infrastructure and promotion. During this time the capital is the main constraint of the industry. However, there is capital support from several parties that give new spirit to develop local culinary. The capital support obtained from savings and credit, local banks, and state banks that provide soft loans. Such is comprehensive review of the culinary tourism strategy development in Metro Lampung. Based on the overall picture of the development strategy, it means that there is already a common understanding in local culinary product development shared by the stakeholders.

4.3 Factors to lift the local confectionary become a tourist attraction in the city's Metro Lampung

Culinary tourism activities cannot be separated from travel itself. Culinary is always attached to the memory because it merges with the physical needs. Culinary tourism is a way to enjoy the local culture.

Classification of common activities such as culinary banquets, food festivals, studying food, food testing, visits to the food industry, watching culinary competitions and visits to the farm while enjoying local food local specialties. Keeping in mind that the main purpose of the activity is to enjoy the culinary and seek for new experience. The main concern of this study is making the local food 
tangible. Factors such as food hygiene and proper packaging that are not present yet need to be addressed.

Referring to the Ministry of Tourism through its Directorate of Destination Planning and Investment, there are several important factors need to be considered in the development of culinary tourism. These are viewed from five aspects such as 1) environmental feasibility, 2) the active role of the government, 3) the feasibility of the business, 4) the feasibility of local culinary, and 5) the feasibility of packaging products and events. The following paragraphs describe in detail the factors mentioned earlier.

The first factor is the environmental feasibility in the utilization of local resources without damaging the environment. It describes the importance to retain the values of local wisdom. Stimulus to improve the local economy and standard of living as well as presenting the philosophy and values of the local culinary culture is also important. The second factor is related to the active role of the Government. It needs to focus on some points such as business licenses issues, production permits, provision of infrastructure, relevant institutions and the control, and promotion. The active role is required by home industry in Metro Lampung.

The third factor concerns on human resources, production, local entrepreneurship, and capital. These points are felt low by the home industry. However, since efforts such as the guidance and counseling from the department of agriculture have made the issues no longer an obstacle. However, capital solutions such as the influx of micro loans offered several state banks and local credit bank with interest rates are still needed.

The fourth factor focuses on the quality of the local food, uniqueness of local food, food hygiene and safety. Quality is in the broad sense that the common snacks are modified into an innovative product that can become an icon of an area.

Product packaging and event need to be considered. Processed snacks are common everywhere but with creativity, processed banana products could be a superior product of Metro Lampung. Packaging using materials from banana could also give some added value as in figure 4.1. Home industry need to involve in local cultural festivals such as the Krakatau Bandar Lampung Festival, Lampung Way Kambas Festival, or Sekura Festival held during the week after Eid in West Lampung. Festivals can be used as a platform to promote processed banana products to be the icon of Metro Lampung.

Beside the home industry, the role of women farmers and the team of Housewives in culinary competition have supported the culinary tourism development. They have had some achievements at both local and national. Some of the achievements are Anugrah National Food (APN) 2014, National Champion level Lampung Province in Metro Awards 2012. In the same year, they were awarded as the first winner in the competition of Food Security and Snacks Market Competition. The existence of home industry initiated by a group of women farmers and team of Housewives are very crucial in the running of the industry.

Present raw data here without comment, using tables and figures if this makes the data clearer. Present by theme, hypothesis, or research question, if possible in the same order as the literature review. Comment on the data, referring 
to the literature and pointing out similarities and differences, explaining these if possible. Return to the aim and research question and show how the aims have been met, and the research question answered. Conclude with some directions for future research or practice, and any limitations of the study.

\section{Conclusion And Recommendation}

Based on the description and analysis of the discussion in this study, it is concluded as follow:

\subsection{Conclusions}

a) City Metro has the potential to be developed into a center of culinary tourism. The snacks made from bananas can be the icon for the city local food.

b) There have been efforts made by the government through Ministry of Agricultural in terms of facilitation and coaching the women farmers as the home industry principals. Support from Ministry of Tourism is still at the initial stage.

c) Empowerment of local communities are given solely to teams of Housewives who also work as farmers.

d) Individuals as members of groups have perceived positively in the improvement in product variants processing knowledge, personal and group skills, confidence, family economy.

\subsection{Suggestions}

The first is addressed to the government through the city tourism office of Metro Lampung in maximizing utilization of the tourism potential. It is expected that the government is more intensive and active in helping local SMEs in terms of providing facilities and counseling, and promoting the local food products, especially processed bananas and derivatives. The city needs to cultivate sociocultural activities such as festivals and cultural ceremony. In addition, it also needs assistance and supporting capital loan to the group of women farmers through cooperatives and soft loans.

Second is aimed at educational institutions. Collaboration with local educational institutions is needed in order to have effective marketing strategy. Educational institution can conduct further research in accordance to its respective fields of knowledge that is beneficial in marketing strategy formulation.

Third is addressed to the public. Awareness on appreciation and preservation of local culinary are necessary. The public also need to preserve and care about the local wisdom.

Lastly is addressed to the media. Television and the print media can broadcast culinary program and culinary review that provide insights about local cuisine in order to increase public awareness and appreciation to local food products. Media can be a bridge in promoting culinary products. 


\section{REFERENCES}

Ariani, R. (1994). Studi Kelayakan Seni Kuliner Bali Mengenai Hidangan Tradisional Provinsi Bali. Singaraja.

Gunn, C. A dengan Var, Turgut (2002). Tourism Planning: Basics, Concepts, Cases, $4^{\text {th }}$ edition. New York: Routledge.

Suriani Ni Made. (2009). "Seni Kuliner Bali Sebagai Salah Satu Daya Tarik Wisata Studi Kasus di Warung Babi Guling Ibu Oka di Kelurahan Ubud, Gianyar, Bali” Program Studi Magister (S2) Kajian Pariwisata (Tesis). Denpasar: Universitas Udayana.

Teguh, Frans. (2011). "Kebijakan Pengembangan Destinasi Wisata Kuliner" Seminar Taste and Travel Indonesia (Makalah). Jakarta: Universitas Pelita Harapan.

Anonim (2012). "Database Bidang Pariwisata Kota Metro" Metro: Pemerintah Kota Metro Dinas Tata Kota dan Pariwisata.

Anonim (2013). "Pertanian, Perikanan dan Kehutanan Dalam Angka" Metro: Pemerintah Kota Metro Dinas Pertanian, Perikanan dan Kehutanan. 